\title{
Clinico, Haemato-Biochemical Changes and Therapeutic Management of Anaplasmosis
}

\author{
Baswaraj Nitture*, Vivek R. Kasaralikar, S. C. Halmandge, B. G. Ravindra, \\ Shrikant Kulkarni and N. A. Patil \\ Department of Veterinary Medicine, Veterinary College Bidar, Karnataka, India \\ *Corresponding author
}

\begin{tabular}{l} 
K e y w o r d s \\
$\begin{array}{l}\text { Anaplasmosis, } \\
\text { haematology, } \\
\text { imidocarb } \\
\text { dipropionate, } \\
\text { oxytetracycline }\end{array}$ \\
\hline Article Info \\
\hline $\begin{array}{l}\text { Accepted: } \\
\text { 12 February } 2020 \\
\text { Available Online: } \\
\text { 10 March } 2020\end{array}$ \\
\hline
\end{tabular}

\section{A B S T R A C T}

The present study was undertaken to know the clinical, haemato-biochemical and therapeutic management of anaplasmosis in bovines. A total of 150 animals showing signs of tick infestation, anorexia, jaundice, anaemia with varied pyrexia were included in the present study. Around $5 \mathrm{ml}$ blood was collected from jugular vein aspectically for haematobiochemical estimation. For therapeutic study, Twelve anaplasmosis affected animals were randomly selected and divided into two groups consisting of six animals in each group. Animals in group I were treated with Oxytetracycline hydrochloride @ $20 \mathrm{mg} / \mathrm{kg}$ body weight intravenously in normal saline daily for 5 consecutive days along with supportive therapy whereas, animals of group II were given Imidocarb dipropionate @ $5 \mathrm{mg} / \mathrm{kg}$ body weight deep intramuscularly as a single dose. Partial to complete anorexia, high fever (104 to $106{ }^{\circ} \mathrm{F}$ ), anaemia, jaundice, debility, decrease in milk yield, hurried respiratory rate, tachycardia and presence of ticks on the body were the consistent clinical signs shown by the affected animals. There was a significant reduction $(\mathrm{P}<0.05)$ in the haemoglobin, packed cell volume, total erythrocyte count of affected animals on day 0 as compared to healthy control group. Biochemical examination revealed significant elevation $(\mathrm{P}<0.05)$ of SGOT, SGPT and total bilirubin concentration on day 0 as compared to the animals of control group. Among Group I animals treated with Oxytetracycline, five animals recovered completely suggestive of 83.33 per cent efficacy whereas, all animals of Group II (06) treated with Imidocarb dipropionate recovered completely by seventh day with cent per cent efficacy rate.

\section{Introduction}

Bovine anaplasmosis formerly known as gall sickness is an infectious, non-contagious, tick borne disease of domesticated and wild ruminants caused by obligate intraerythrocytic parasites of family Anaplasmataceae and genus Anaplasma (Radostitis et al., 2000). A. marginale is primarily a pathogen of bovine anaplasmosis (Rymaszewska and Grenda 2008) which is a small, coccoid to ellipsoidal, often pleomorphic, non-motile Alphaproteobacteria that resides and replicate in membrane-bound vacuoles within the cytoplasm of eukaryotic host cells (Dumler $e t$ al., 2006). Routes of transmission are mainly by biological, mechanical and transplacental 
(Zaugg, 1985). Infection is characterised by progressive haemolytic anaemia associated with high fever, jaundice, decreased milk production, abortion, loss of appetite coupled with dullness/depression, rapid deterioration of the physical condition (Al Saad 2007). Demonstrations of the infective stages in thin blood smears stained with Giemsa, a traditional laboratory method, newer diagnostic aids such as Polymerase chain reaction- based method has been developed which is capable of detecting low levels of infection in infected as wellas carrier animals. Use of oxytetracycline and imidocarb (Richey, 1981) appears to be more promising in the treatment of bovine anaplasmosis. Keeping in view the economic losses due to anaplasmosis, the present study was designed to know the clinical, haematobiochemical changes and therapeutic management of anaplasmosis.

\section{Materials and Methods}

A total of 150 animals showing signs of tick infestation, anorexia, jaundice, anaemia with varied pyrexia were included in the present study. Around $2 \mathrm{ml}$ blood was collected from jugular vein in vacutainers containing EDTA as an anticoagulant for haematological studies using BD Vacutainer Eclipse blood collection needle (BD, Franklin, USA).

For biochemical estimations $3 \mathrm{ml}$ blood was collected in vials coated with clot activator and blood was allowed to coagulate. Serum was separated by centrifugation at $2500 \mathrm{rpm}$ for 10 minutes and serum was separated in Eppendorf tubes.

\section{Haematological parameters}

Total Erythrocyte Count (TEC), Haemoglobin $(\mathrm{Hb})$, Packed Cell Volume (PCV), Mean Corpuscular Volume (MCV), Mean Corpuscular Haemoglobin $(\mathrm{MCH})$ and Mean
Corpuscular Haemoglobin Concentration (MCHC) were estimated using fully automatic blood cell counter model PCE-210 $\left(\right.$ ERMA INC $^{\circledR}$.)

\section{Biochemical Parameters}

Serum glutamic pyruvate transaminase (SGPT), Serum glutamic oxaloacetate transaminase (SGOT) (Reitman and Frankel, 1957) and Serum total bilirubin (Tietz, 1976) were analyzed using ARTOS Elita ${ }^{\circledR}$ semiautomatic biochemical analyser.

\section{Clinical parameters}

Clinical parameters namely temperature, respiration rate, heart rate, appearance of conjunctival mucous membrane and ruminal contractions were recorded.

\section{Therapeutic management}

Twelve animals suffering from Anaplasmosis were randomly selected and divided into two groups consisting of six animals in each group. Animals in group I were treated with Oxytetracycline hydrochloride @ $20 \mathrm{mg} / \mathrm{kg}$ body weight intravenously in normal saline daily for 5 consecutive days along with supportive therapy whereas, animals of group II were given Imidocarb dipropionate @ 5 $\mathrm{mg} / \mathrm{kg}$ body weight deep intramuscularly as a single dose.

Both the groups received uniform supportive therapy with Iron tonics (Inj. Ferritas, Intas pharma) @ once in two days for a week @ $1 \mathrm{ml} / 50 \mathrm{~kg}$ body weight intra muscularly, antipyretic like meloxicam (Inj. Melonex, Intas pharma) @ $0.5 \mathrm{mg} / \mathrm{kg}$ body weight daily for 3-5 days intramuscularly. B-complex with liver extract (Inj.Bivinal Plus, Alembic pharmaceuticals) @ 10ml every day for 3-5 days deep intramuscularly. 


\section{Statistical analysis}

The haematological, biochemical and vital parameter values obtained before treatment and after treatment were subjected to statistical analysis by one-way ANOVA using Statistical Package for Social Sciences (SPSS) version 2.0. Differences between means were tested using Duncan's multiple comparison test and significance was set at 5 per cent $(\mathrm{p}<0.05)$ (Snedecor and Cochran 1994).

\section{Results and Discussion}

Partial to complete anorexia, high fever (104 to $106{ }^{\circ} \mathrm{F}$ ), depression, anaemia, jaundice, debility, decrease in milk yield, hurried respiratory rate, tachycardia and presence of ticks on the body were the consistent clinical signs shown by the affected animals used for the study. Similar clinical signs in anaplasmosis were observed by earlier workers Kumar et al., (2015) and Szabara et al., (2016) in dairy cattle.

The affected animals showed high rectal temperature at 0 day $(105.80 \pm 0.28$ and $105.66 \pm 0.20)$ and as therapy progressed it showed reduction in rectal temperature and returned to normal by $7^{\text {th }}$ day post treatment $(100.22 \pm 0.34$ and $100.22 \pm 0.34)$. Significant $(\mathrm{P}<0.05)$ increase in the rectal temperature on 0 day when compared to healthy control group indicative of pyrexia in the present investigation was in accordance with Kumar et al., (2015) in dairy cattle. Parasitized erythrocytes removed by phagocytosis in the reticular endothelial system, with release of acute phase inflammatory reactants has been attributed for development of fever in anaplasmosis (Radostits et al., 2000).

The significant increase in the respiratory rate on 0 day $(37.67 \pm 1.76$ and $49.33 \pm 5.44)$ was observed in anaplasmosis affected animals of
Group I and Group II, respectively, when compared to healthy control group, which returned to normal on $7^{\text {th }}$ day post treatment in both study groups. Similar observations were reported by Jaswal et al., (2014) in dairy cattle. The increased respiratory rate observed in present study could be attributed as compensatory mechanism in order to make up oxygen requirements due to decreased oxygen carrying capacity of RBC's due to lowered haemoglobin concentration in anaplasmosis affected animals.

The affected animals of Group I and II showed increased heart rate on the day of presentation $(86.83 \pm 3.61$ and $90.83 \pm 1.72)$. However, it returned to normal on $7^{\text {th }}$ day post treatment. This increase was significantly $(\mathrm{P}<0.05)$ higher when compared to healthy control group. Similar observations were made by Vatsya et al., (2013) in anaplasmosis affected animals. The increased heart rate in anaplasmosis has been attributed to severe anaemia of the affected animals in order to compensate demand by peripheral organs.

Decreased ruminal contractions in affected animals of Group I and II returned to normal $(2.33 \pm 0.19$ and $2.33 \pm 0.21)$ on $7^{\text {th }}$ day post treatment which did not differ significantly $(\mathrm{P}<0.05)$ from values of control group. Anaplasmosis is also named as gall sickness and anorexia has been observed as important clinical signs of the disease (Radostits et al., 2000).

In present study, all the cattle suffering from anaplasmosis showed pale to icteric conjunctival mucous membrane on the day of presentation, however visible mucous membrane was found to be light pink in group I and II on $7^{\text {th }}$ day post treatment. Similar results were opined by Vetrivel et al., (2018) in dairy cattle and Szabara et al., (2016) HF cross cows. Pallor conjunctival mucous membrane has been attributed to anaemia 
whereas icteric conjunctival mucous membrane could be attributed to intravascular haemolysis and increased amount of indirect bilirubin in the anaplasmosis affected animals (Radostits et al., 2000). Haematinics along with liver extract in treatment regimen might have helped to regain normalcy after treatment.

\section{Haematological parameters}

\section{Total erythrocyte count (millions/ $\mu \mathrm{I})$}

The anaplasmosis affected animals in Group I and II on $0^{\text {th }}$ day significantly showed lower values $(4.35 \pm 0.76$ and $4.28 \pm 0.16$ respectively) when compared with that of control healthy group (7.25 \pm 0.14$)$. However, it returned towards normalcy $(5.58 \pm 0.12$ and $5.91 \pm 0.11)$ on $7^{\text {th }}$ day post treatment in both study groups which did differ significantly $(\mathrm{P}<0.05)$ from values of control group $($ Table 2). On the day of presentation animals were anaemic indicating severe reduction in TEC and were apparently normal on $7^{\text {th }}$ day post treatment. Similar results are observed by Ganguly et al., (2017) in crossbred cows and Maharana et al., (2016) in dairy animals. Considerable increase in the haemoglobin concentration was noticed in all the treated animals and similar results were noted by Szabara et al., (2016) and Ganguly et al., (2017) in crossbred cows.

\section{Haemoglobin $(\mathrm{g} / \mathrm{dL})$ and packed cell volume (\%)}

The anaplasmosis affected animals in Group I and II on $0^{\text {th }}$ day showed lower haemoglobin values $(5.58 \pm 0.06$ and $5.67 \pm 0.07$ respectively) and differed significantly $(\mathrm{P}<0.05)$ from the control healthy group (9.93 $\pm 0.27)$. The mean haemoglobin values in group I and II on $7^{\text {th }}$ day post treatment were $8.15 \pm 0.76$ and $8.35 \pm 0.13$ respectively which did differ significantly $(\mathrm{P}<0.05)$ from values of control group. However, showed trend of returning towards normalcy on $7^{\text {th }}$ day post treatment (Table 2).

In the present study, Group I and II on the day of presentation showed lower PCV values $(24.32 \pm 0.80$ and $23.73 \pm 0.80$ respectively $)$ and differed significantly $(\mathrm{P}<0.05)$ from the control healthy group (37.75 \pm 0.99). The mean PCV values in group I and II on $7^{\text {th }}$ day post treatment $(28.02 \pm 0.59$ and $29.65 \pm 0.61$ respectively) which did differ significantly $(\mathrm{P}<0.05)$ from values of control group. However, showed trend of returning towards normalcy on $7^{\text {th }}$ day post treatment (Table 2).

The present findings of significant reduction in haematocrit values on 0 day when compared to healthy control group are in accordance with observations reported by Maharana et al., (2016) in dairy cattle and Kumar et al., (2015) in crossbred cattle. Anaemia due to intravascular haemolysis and phagocytosis of parasitized erythrocytes is a hallmark observation of bovine anaplasmosis (Radostits et al., 2000). Diminished values of haemogram in the present investigation could be attributed to these mechanisms. The appearance of anti-erythrocyte antibodies late in the acute stage has also been attributed to exacerbate the anaemia (Richeyand Palmer, 1990) in cases of anaplasmosis.

\section{Erythrocytic indices}

\section{Mean corpuscular volume (fl)}

The mean corpuscular volume on 0 day in group I and group II were $55.94 \pm 1.79$ and $55.58 \pm 1.78$ respectively and did not differ significantly $(\mathrm{P}<0.05)$ from the control group $(52.09 \pm 0.98)$ mean and SE value. The mean corpuscular volume values in group I and II on $7^{\text {th }}$ day post treatment were $50.21 \pm 0.84$ and $50.21 \pm 0.84$. They did not differ significantly $(\mathrm{P}<0.05)$ from values of control 
group, but showed a trend to return towards normalcy on $7^{\text {th }}$ day post treatment (Table 2).

\section{Mean corpuscular haemoglobin (pg)}

The values of mean corpuscular haemoglobin on 0 day in group I and group II were $12.87 \pm$ 0.36 and $13.30 \pm 0.42$ respectively and did not differ significantly $(\mathrm{P}<0.05)$ from the control group $(13.70 \pm 0.19)$ mean and $\mathrm{SE}$ value. Though, the mean corpuscular haemoglobin values in group I and II on $7^{\text {th }}$ day post treatment were $14.61 \pm 0.17$ and $14.12 \pm 0.20$ which differ significantly $(\mathrm{P}<0.05)$ from values of control group, they show a trend of returning towards normalcy on $7^{\text {th }}$ day post treatment (Table 2).

\section{Mean corpuscular haemoglobin concentration $(\mathrm{g} / \mathrm{dL})$}

The mean corpuscular haemoglobin concentration on 0 day in group I and group II were $23.11 \pm 0.95$ and $24.03 \pm 0.96$ respectively and did not differ significantly $(\mathrm{P}<0.05)$ from the control group $(26.37 \pm$ 0.79) mean and SE value. Though the mean corpuscular haemoglobin concentration values in group I and II on $7^{\text {th }}$ day post treatment were $29.14 \pm 0.46$ and $28.22 \pm 0.69$ which did not differ significantly $(\mathrm{P}>0.05)$ from values of control group, it returned towards normalcy on $7^{\text {th }}$ day post treatment (Table 2).

As the erythrocytic indices are arithmetic representatives of haemogram, corresponding decrease has been observed in $\mathrm{MCH}$ and MCHC. Mean MCH and MCHC values before treatment ( 0 day) were significantly $(\mathrm{P}<0.05)$ lower when compared to healthy control group. The values of $\mathrm{MCH}$ and $\mathrm{MCHC}$ improved on $7^{\text {th }}$ day (post treatment) when compared to before treatment in both study groups. Similar decrease in $\mathrm{MCH}$ and $\mathrm{MCHC}$ values has been observed by Ashuma et al., (2013) and Maharana et al., (2016) in dairy cattle. Though the mean values of MCV were significantly increased on $0^{\text {th }}$ day when compared to healthy control group, MCV concentrations were within normal physiological limits on $7^{\text {th }}$ day post treatment.

Macrocytic hypochromic anaemia in cases of bovine anaplasmosis reported by Ashuma et $a l .$, (2013) is in close agreement with present investigation which suggest normocytic hypochromic anaemia.

\section{Biochemical parameters}

\section{Serum transaminases (SGOT and SGPT)} (IU)

The serum glutamic oxaloacetic transaminase on 0 day in group I and group II were $167.13 \pm 21.98$ and $158.33 \pm 14.03$ respectively and differed significantly $(\mathrm{p}<0.05)$ from the control group (67.92 \pm 3.08$)$. The mean serum glutamic oxaloacetic transaminase values in group I and II on $7^{\text {th }}$ day post treatment were $114.43 \pm 13.24$ and $79.44 \pm 10.97$ which did not differ significantly $(\mathrm{p}<0.05)$ from values of control group, it returned towards normalcy on $7^{\text {th }}$ day post treatment (Table 3 ).

Serum glutamate pyruvate transaminase on 0 day in group I and group II were $90.56 \pm 25.48$ and $76.63 \pm 8.89$ respectively with significant $(\mathrm{p}<0.05)$ difference from the control group (18.86 \pm 3.71$)$. Though, the mean serum glutamate pyruvate transaminase values in group I and II on $7^{\text {th }}$ day post treatment were $55.68 \pm 11.75$ and $35.53 \pm 6.59$ though these values did not differ significantly $(p<0.05)$ from values of control group, they returned towards normalcy on $7^{\text {th }}$ day post treatment (Table 3).

Mean SGOT concentration before treatment (0 day) was significantly higher when 
compared to after treatment $\left(7^{\text {th }}\right.$ day) in both the study groups. The two-fold increase in the SGOT concentration in affected animals on 0 day when compared to healthy control group was indicative of severe hepatic insufficiency.

Mean SGPT concentration before treatment ( 0 day) was significantly higher when compared to after treatment ( $7^{\text {th }}$ day) in both the study groups. The increase in the SGPT concentration in affected animals on 0 day when compared to healthy control group was indicative of hepatic damage.

SGOT and SGPT have been reported to be liver specific enzyme for bovine and its elevation has been linked with hepato-cellular damage (Kaneko et al., 2008). Elevated SGOT and SGPT in the anaplasmosis affected animals in the present study could be attributed to hepatic injury due to increased load of phagocytosed parasitized erythrocytes in hepatic RES as reported by Radostitis et $a l$. , (2000) and Kataria and Bhatia, (1991).

\section{Serum bilirubin (total bilirubin) $\mathrm{mg} / \mathrm{dl}$}

The mean values of total bilirubin were significantly higher before $(2.88 \pm 0.14$ and $3.75 \pm 0.68)$ treatment when compared to $7^{\text {th }}$ day post treatment in both the study groups. The increase in bilirubin on 0 day when compared to healthy control group was indicative of hyperbilirubinemia (Indirect bilirubin) in affected animals suggestive of prehepatic jaundice. The observations of present investigation are corroborated with earlier reports of Ashuma et al., (2013) in 320 cattle.

\section{Therapeutic studies}

Out of six animals in Group I treated with Oxytetracycline at $20 \mathrm{mg}$ per $\mathrm{kg}$ body weight intravenously in $500 \mathrm{ml}$ normal saline for 5 days daily, five animals recovered completely as revealed by clinical, haematological, biochemical improvement and absence of intracellular Anaplasma organisms by seventh day, suggestive of 83.33 per cent (Table 4) efficacy, all animals of Group II (06) treated with Imidocarb dipropionate at $5 \mathrm{mg}$ per $\mathrm{kg}$ body weight deep intra muscularly single dose, recovered completely by seventh day with the efficacy rate of 100 per cent (Table 4).

Table.1 Clinical observation at 0 day and $7^{\text {th }}$ day after treatment in Different groups of cattle with Anaplasmosis

\begin{tabular}{|c|c|c|c|c|c|}
\hline Parameters & $\begin{array}{c}\text { Control } \\
\text { group }\end{array}$ & \multicolumn{2}{|c|}{ BT Mean \pm SE (0 day) } & \multicolumn{2}{c|}{ AT Mean \pm SE (7th day) } \\
\cline { 3 - 6 } & Group I & Group II & Group I & Group II \\
\hline $\begin{array}{c}\text { Rectal } \\
\text { temperature }\end{array}$ & $100.30 \pm 0.16^{\mathrm{a}}$ & $105.80 \pm 0.28^{\mathrm{b}}$ & $105.66 \pm 0.20^{\mathrm{b}}$ & $\begin{array}{c}100.20 \pm \\
0.15^{\mathrm{a}}\end{array}$ & $100.22 \pm 0.34^{\mathrm{a}}$ \\
\hline $\begin{array}{c}\text { Respiration } \\
\text { rate per min }\end{array}$ & $22.83 \pm 1.56^{\mathrm{a}}$ & $37.67 \pm 1.76^{\mathrm{b}}$ & $49.33 \pm 5.44^{\mathrm{c}}$ & $23.50 \pm 1.33^{\mathrm{a}}$ & $24.66 \pm 0.88^{\mathrm{a}}$ \\
\hline $\begin{array}{c}\text { Heart rate } \\
\text { beats/min }\end{array}$ & $62.50 \pm 2.18^{\mathrm{a}}$ & $86.83 \pm 3.61^{\mathrm{b}}$ & $90.83 \pm 1.72^{\mathrm{b}}$ & $67.50 \pm 1.31^{\mathrm{a}}$ & $68.00 \pm 1.06^{\mathrm{a}}$ \\
\hline $\begin{array}{c}\text { Ruminal } \\
\text { contractions } \\
\text { per 3 minutes }\end{array}$ & $2.33 \pm 0.21^{\mathrm{a}}$ & $0.33 \pm 0.21^{\mathrm{b}}$ & $0.33 \pm 0.19^{\mathrm{b}}$ & $2.33 \pm 0.19^{\mathrm{a}}$ & $2.33 \pm 0.21^{\mathrm{a}}$ \\
\hline
\end{tabular}

*Means bearing different superscripts differ significantly $(\mathrm{P}<0.05)$ 
Table.2 Haematological parameters at 0 day and $7^{\text {th }}$ day after treatment in different groups of cattle with Anaplasmosis

\begin{tabular}{|c|c|c|c|c|c|}
\hline \multirow{2}{*}{ Parameters } & $\begin{array}{c}\text { Control } \\
\text { group }\end{array}$ & \multicolumn{2}{|c|}{ BT Mean \pm SE } & \multicolumn{2}{c|}{ AT Mean \pm SE } \\
\cline { 3 - 6 } & & Group I & Group II & Group I & Group II \\
\hline TEC (10 $/ \boldsymbol{\mu l})$ & $7.25 \pm 0.14^{\mathrm{a}}$ & $4.35 \pm 0.76^{\mathrm{b}}$ & $4.28 \pm 0.16^{\mathrm{b}}$ & $5.58 \pm 0.12^{\mathrm{c}}$ & $5.91 \pm 0.11^{\mathrm{c}}$ \\
\hline Hb (g/dL) & $9.93 \pm 0.27^{\mathrm{a}}$ & $5.58 \pm 0.06^{\mathrm{b}}$ & $5.67 \pm 0.07^{\mathrm{b}}$ & $8.15 \pm 0.76^{\mathrm{c}}$ & $8.35 \pm 0.13^{\mathrm{c}}$ \\
\hline PCV (\%) & $37.75 \pm 0.99^{\mathrm{a}}$ & $24.32 \pm 0.80^{\mathrm{b}}$ & $23.73 \pm 0.80^{\mathrm{b}}$ & $28.02 \pm 0.59^{\mathrm{c}}$ & $29.65 \pm 0.61^{\mathrm{c}}$ \\
\hline MCV (fl) & $52.09 \pm 0.98^{\mathrm{ab}}$ & $55.94 \pm 1.79^{\mathrm{a}}$ & $55.58 \pm 1.78^{\mathrm{a}}$ & $50.21 \pm 0.84^{\mathrm{b}}$ & $50.21 \pm 0.84^{\mathrm{b}}$ \\
\hline MCH (pg.) & $13.70 \pm 0.19^{\mathrm{ab}}$ & $12.87 \pm 0.36^{\mathrm{a}}$ & $13.30 \pm 0.42^{\mathrm{ab}}$ & $14.61 \pm 0.17^{\mathrm{c}}$ & $14.12 \pm 0.20^{\mathrm{c}}$ \\
\hline MCHC (\%) & $26.37 \pm 0.79^{\mathrm{a}}$ & $23.11 \pm 0.95^{\mathrm{b}}$ & $24.03 \pm 0.96^{\mathrm{b}}$ & $29.14 \pm 0.46^{\mathrm{c}}$ & $28.22 \pm 0.69^{\mathrm{ac}}$ \\
\hline
\end{tabular}

* Means bearing different superscripts differ significantly $(\mathrm{P}<0.05)$

Table.3 Biochemical parameters at 0 day and $7^{\text {th }}$ day after treatment in different groups of cattle with Anaplasmosis

\begin{tabular}{|c|c|c|c|c|c|}
\hline Parameters & $\begin{array}{c}\text { Control } \\
\text { group }\end{array}$ & \multicolumn{2}{|c|}{ BT Mean \pm SE } & \multicolumn{2}{c|}{ AT Mean \pm SE } \\
\cline { 3 - 6 } & Group I & Group II & Group I & Group II \\
\hline SGOT (IU/L) & $\begin{array}{c}67.92 \\
\pm 3.08^{\mathrm{a}}\end{array}$ & $167.13 \pm 21.98^{\mathrm{c}}$ & $158.33 \pm 14.03^{\mathrm{c}}$ & $114.43 \pm 13.24^{\mathrm{b}}$ & $79.44 \pm 10.97^{\mathrm{ab}}$ \\
\hline SGPT (IU/L) & $18.86 \pm 3.71^{\mathrm{a}}$ & $90.56 \pm 25.48^{\mathrm{b}}$ & $76.63 \pm 8.89^{\mathrm{b}}$ & $55.68 \pm 11.75^{\mathrm{ab}}$ & $35.53 \pm 6.59^{\mathrm{a}}$ \\
\hline $\begin{array}{c}\text { Serum bilirubin } \\
\text { (Total bilirubin) } \\
\text { mg/dl }\end{array}$ & $1.23 \pm 0.30^{\mathrm{a}}$ & $2.88 \pm 0.14^{\mathrm{bc}}$ & $3.75 \pm 0.68^{\mathrm{c}}$ & $2.02 \pm 0.09^{\mathrm{ab}}$ & $1.81 \pm 0.17^{\mathrm{ab}}$ \\
\hline
\end{tabular}

* Means bearing different superscripts differ significantly $(\mathrm{P}<0.05)$

Table.4 Therapeutic efficacy of different drugs

\begin{tabular}{|c|c|c|c|c|}
\hline Groups & $\begin{array}{c}\text { No. of } \\
\text { cattle }\end{array}$ & Treatment & $\begin{array}{c}\text { No. of animal } \\
\text { recovered completely } \\
\text { by } \mathbf{7}^{\text {th }} \text { day }\end{array}$ & $\begin{array}{c}\text { Efficacy } \\
(\%)\end{array}$ \\
\hline I & 06 & Oxytetracycline $50 \mathrm{mg} / \mathrm{ml}$ & 05 & 83.33 \\
\hline II & 06 & Imidocarb dipropionate $12 \%$ & 06 & 100 \\
\hline
\end{tabular}


Table.5 Cost - Efficacy of different drugs

\begin{tabular}{|c|c|c|c|c|c|}
\hline Treatment & $\begin{array}{c}\text { Cost of } \\
\text { drug } \\
\text { (Rs) }\end{array}$ & $\begin{array}{c}\text { Cost incurred } \\
\text { in treatment } \\
(\mathbf{R s})\end{array}$ & $\begin{array}{c}\text { Cost of } \\
\text { supportive } \\
\text { therapy (Rs) }\end{array}$ & $\begin{array}{c}\text { Total } \\
\text { cost } \\
(\mathbf{R s})\end{array}$ & $\begin{array}{c}\text { Efficacy } \\
(\%)\end{array}$ \\
\hline $\begin{array}{c}\text { Oxytetracycline } \\
\text { HCl }\end{array}$ & 66 & 396 & 530 & 926 & 83.33 \\
\hline $\begin{array}{c}\text { Imidocarb } \\
\text { dipropionate }\end{array}$ & 160 & 192 & 530 & 722 & 100 \\
\hline
\end{tabular}

Oxytetracycline - a broad spectrum tetracycline group of antibiotic acts by interfering the ability of protozoa to produce essential proteins by inhibiting 30s ribosome without which a protozoon cannot grow, multiply and increase in number which aids host immune system to take upper hand and kill the protozoa. (Srivastava, 1989).

The mode of action of imidocarb is to interfere with the production and/or utilization of polymers and prevention of entry of inositol parasitized erythrocytes (Neill et al., 2010). Therapeutic trial clearly indicated superiority of imidocarb with cent percent efficacy as compared to oxytetracycline $(83.33 \%)$.

The haemoprotozoan diseases pose an increased production loss as well as treatment cost to the poor farmers and in order to reduce the losses, cost effective treatment is also a necessary. The cost incurred for the treatment with oxytetracycline for 5 days for one cattle was Rs. 396 with the efficacy of 83.33 per cent whereas treatment with imidocarb dipropionate needed Rs. 192 with efficacy of 100 per cent (Table 5).

Cent per cent efficacy along with cost effective economy (Rs. 192) of imidocarb was found superior to oxytetracycline hydrochloride and hence is recommended for treatment for bovine anaplasmosis.

\section{References}

Al- Saad, K.A.M. (2007). The efficacy of imidocarb, oxytetracycline $20 \%$ and diaminazine in the treatment of naturally infected cows with anaplasmosis. Iraqi Journal of Veterinary Sciences, 21(2):307-316.

Ashuma, A., Sharma, A., Singla, L.D., Kaur, P., Bal, M.S., Batth, B.K. and Juyal, P.D. (2013). Prevalence and haematobiochemical profile of Anaplasmamarginale infection in dairy animals of Punjab (India). Asian Pacific Journal of Tropical Medicine, Pp:139144.

Dumler, J.S., Rikishia, Y., Dasch, G.A., Brenner, D.J., Krieg, N.R. and Stanley, J.T. (2006). Family II. Anaplasmataceae. In: (Eds), Bergeys Manual of systemic bacteriology: The protobacteria. Part C Springer-Verlag, US, 2:117-120.

Ganguly, A., Bisla, R. S., Singh, H., Bhanot, V., Kumar, A., Kumari, S., Maharana, B.R. and Ganguly, I. (2017). Prevalence and haemato-biochemical changes of tick-borne haemoparasitic diseases in crossbred cattle of Haryana, India. Indian journal of Animal sciences, 87(5):552-557.

Jaswal, H., Singh, M.B., Singla, L.D., Sharama, A., Kaur, P., Mukhopadhyayc, S. and Juyal, P.D., 
2014. Application of msp1 $\beta$ PCR and 16S rRNA semi nested PCRRFLP for detection of persistent anaplasmosis in tick infested cattle. International J.AdvancedReaserch., 2(8):188-196.

Kaneko, J.J., Bruss, M.L. and Harvey, J.W. (2008). Clinical Biochemistry of Domestic Animals. $6^{\text {th }} \mathrm{Edn}$. Elsvier.

Kataria, N. and Bhatia, J.S. (1991). Activity of some enzymes in the serum of dromedary camels. Res Vet Sci., 51: 174-176.

Kumar, K., Sindhu, N., Charaya, G., Kumar, A., Kumar, P., Chandratere, G., Agnihotri, D. and Khurana, R. (2015). Emerging status of anaplasmosis in cattle in Hisar. Veterinary World .Org, 14(8):768-771.

Maharana, B.R., Kumar, B., Prasad, A., Patbandha, T.K., Sudhakar, N.R., Joseph, J.P. and Patel, B.R. (2016). Prevalence and assessment of risk factors for haemoprotozoan infections in cattle and buffaloes of South-West Gujarat, India. Indian J. Anim. Res, 50(5):733-739.

Neill, P.M., Barton, V.E. and Ward, S.A. (2010). The molecular mechanism of action of artemisinin- The debate continues. Molecules, 15(3):1705-1721.

Radostitis, O.M., Gay, C.C., Blood, D.C. and Hinchliff, K.W. (2000). Veterinary Medicine: A Text Book of the Diseases of Cattle, Sheep, Goats and Horses, W.B. Saunders Co., London, New York, Philadelephia, 9:1261.

Reitman, S. and Frankel, S. (1957). A calorimetric method for the determination of serum Glutamic Oxaloacetic and Pyruvic transaminases. American J. Clin. Pathol. 28: 56.

Richey, E. J., 1981. Bovine anaplasmosis. In Howard R. J. (ed.), Current Veterinary Therapy Food Animal Practice. W. B.
Saunders, Co., Pp:767-772.

Richey, E.J. and Palmer, G.H. (1990). Bovine Anaplasmosis. Compend. Coutin. Educ. Pract. Vet, 12:166-168.

Rymaszewska, A. and Grenda, S. (2008). Bacteria of the genus Anaplasma characteristics of Anaplasma and their vectors: A review. VeterinarniMedicina, 53(11): 573-584.

Snedecor, G.W. and Cochran, W.G. (1994). Statistical methods (Eighth Edition). Calcutta. India: Oxford and IBH publishing. Co.

Srivastava, R.V.N. (1989). Chemotherapeutic use of two indigenous drugs in infection of Theileriaannulatain cattle. Ind. Vet. Med. J, 11:106-107.

Szabara, A., Majer, J., Ozsvari, L., Jakab, C. and Baumgartner, W. (2016). Coinfection with bovine viral diarrhea virus and Anaplasmamarginale in a dairy cattle herd may lead to acute bovine anaplasmosis. Veterinarni Medicina., 61(9):504-515.

Tietz, N.W. (1976). Fundamentals of clinical chemistry. W.B. Saunders Co., Philadelphia.

Vatsya, S., Kumar, R. R., Singh, V.S. and Arunraj, M. R. (2013). Anaplasmamarginale infection in a buffalo: A case report. Vet. Res. International, 1(2):51-53.

Vetrivel, D., Pandian, A.S.S., Shilpashree, J. and Boopathy, M. (2018). An empirical study on the prevalence of anaplasmosis in North-Eastern agro-climatic zone of Tamil Nadu, India. Journal of Entomology and zoology studies. 6(3):368-371.

Zaugg, J.I. (1985). Bovine anaplasmosis: transplacental transmission as it relates to stage of gestation. Am. J. Vet. Res.46(3):570-572. 


\section{How to cite this article:}

Baswaraj Nitture, Vivek R. Kasaralikar, S. C. Halmandge, B. G. Ravindra, Shrikant Kulkarni and Patil. N. A. 2020. Clinico, Haemato-Biochemical Changes and Therapeutic Management of Anaplasmosis. Int.J.Curr.Microbiol.App.Sci. 9(03): 1440-1449. doi: https://doi.org/10.20546/ijcmas.2020.903.168 